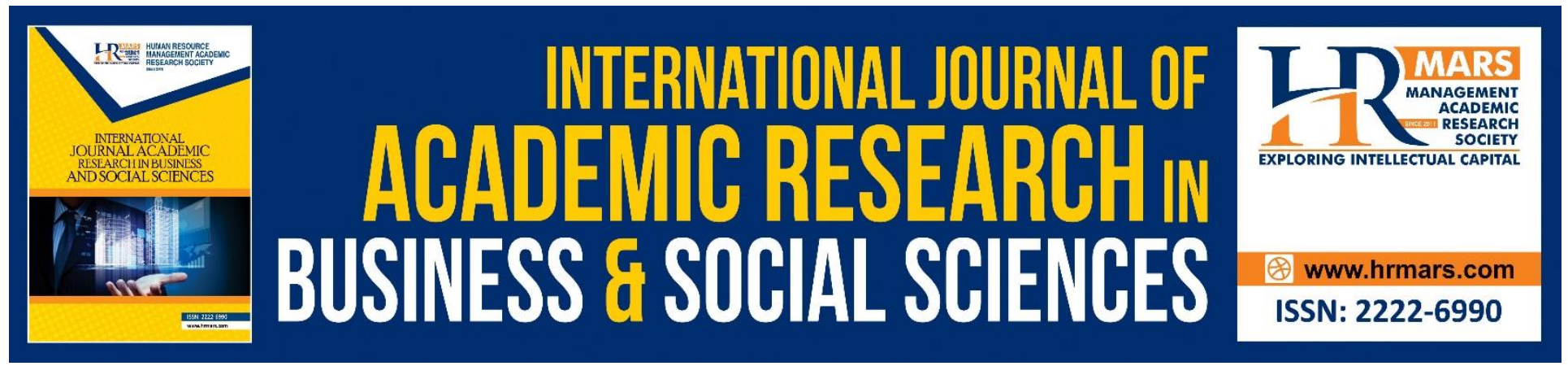

\title{
Demystifying Thought Leadership in the Malaysian Service Industry
}

\section{Ong Choon Hee and Yeo Hui Ying}

To Link this Article: http://dx.doi.org/10.6007/IJARBSS/v9-i5/5873

DOI: 10.6007/IJARBSS/v9-i5/5873

Received: 13 March 2019, Revised: 06 April 2019, Accepted: 28 April 2019

Published Online: 24 May 2019

In-Text Citation:(Hee \& Ying, 2019)

To Cite this Article: Hee, O. C., \& Ying, Y. H. (2019). Demystifying Thought Leadership in the Malaysian Service Industry. International Journal of Academic Research Business and Social Sciences, 9(5), 325-334.

Copyright: (C) 2019 The Author(s)

Published by Human Resource Management Academic Research Society (www.hrmars.com)

This article is published under the Creative Commons Attribution (CC BY 4.0) license. Anyone may reproduce, distribute, translate and create derivative works of this article (for both commercial and non-commercial purposes), subject to full attribution to the original publication and authors. The full terms of this license may be seen

at: http://creativecommons.org/licences/by/4.0/legalcode

Vol. 9, No. 5, 2019, Pg. 325 - 334

http://hrmars.com/index.php/pages/detail/IJARBSS

JOURNAL HOMEPAGE

Full Terms \& Conditions of access and use can be found at http://hrmars.com/index.php/pages/detail/publication-ethics 


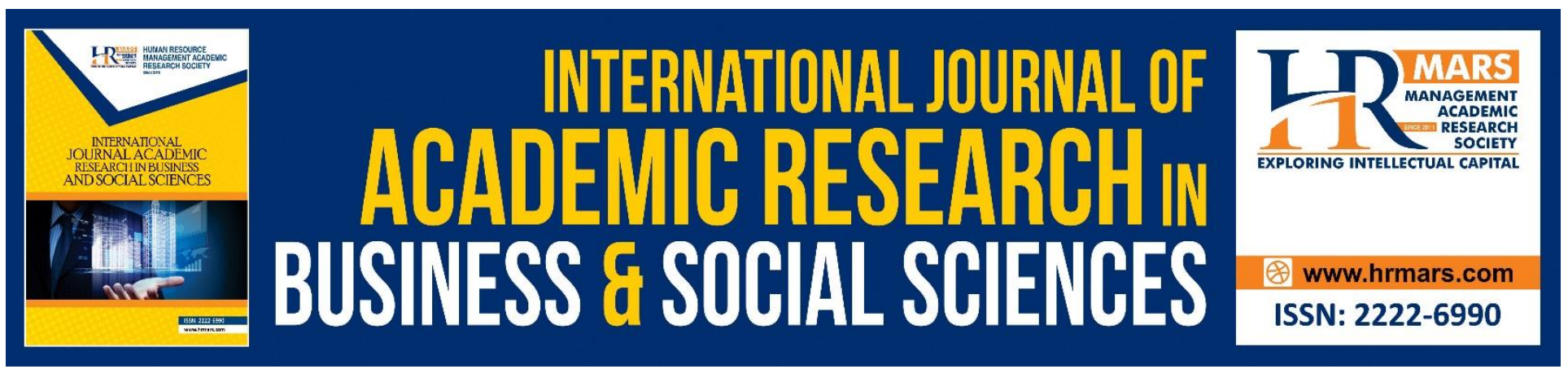

\title{
Demystifying Thought Leadership in the Malaysian Service Industry
}

\author{
Ong Choon Hee and Yeo Hui Ying \\ Azman Hashim International Business School, Universiti Teknologi Malaysia, Johor, Malaysia. \\ Corresponding Author Email: ongchoonhee@gmail.com
}

\begin{abstract}
It is worth to have further in-depth discussion with the emerging importance of the term: Thought leadership. Creating a thought leadership culture is beneficial. Thought leaders are the trusted sources who play important role in inspiring people with the realization of innovation ideas. Time passes, thought leaders provide transformational influence on the industry, focus niche or even across the entire world. Today, thought leadership is not possessed by an individual, but also tied with the organization. Some companies embraced thought leadership qualities and had been recognized as thought leadership companies. There are differences between thought leadership and traditional leadership, especially in the aspects of authority level, leadership style, information sharing and way of solving issues. Looking at and analysing the largest industry contributor to the Malaysian economy: Services industry, there is a lack of revolutionary and visionary thought leaders. This highlights the sense of urgency in taking drastic measures in cultivating thought leadership in the service industry. Ways of implementing thought leadership has also been mentioned such as stand out from the talent pools and grab industry experts' attention. Several common mistakes that companies should prevent were also highlighted such as copying others, lack of strategy, delivering low-quality content, misleading self-perception and emphasis on self-promotion.
\end{abstract}

Keywords: Thought leadership, service industry, digital and creative world.

\section{Literature Review of Thought Leadership}

According to McCrimmon (2005), thought leadership is an integral part of organizational structure which focused on innovation, promoting new ideas and initiatives rather than focusing on people management. A thought leader sparks brand new ideas, implements the ideas and creates a blueprint for people to follow. Israel (2012) added on that thought leader is someone who had ideas that granted attention. A thought leader has the ability to foresee the future and sets a course of action for others to follow. Thought leaders reenergize current best practices and generate with better practices that often cause the great disruption to the market. Few real role models were highlighted in Israel's articles such as Steve Jobs and Bill Gates. Both believed in different computer systems, the 
reality is both were right and today billions of people are following them. Apart from that, Dunlap and Rakowich (as cited in Fallon, 2016) mentioned that thought leaders are able to speculate the future among industry colleagues and peers, provide intelligent insights and opinions and inspire and influence others to implement their ideas. Thought leaders predict and recognize trends before they come and apply the insights to deliver and achieve actual business results (Akram as cited in Fallon, 2016). Steffens (2018) also stated that practicing thought leadership is influential, not only because of how a person completes tasks, but his or her ability to explain why some approaches are better. He also further explained that thought leadership is not limited to providing high product and service quality, but about dealing with the strategic problems with higher level of thinking in the industry. In summary, thought leaders are individuals but not company. On the other perspectives, many organizations encourage, embrace individual thought leaders, and then earn recognition as "Thought Leadership Company". Llopis (2014) shared that thought leadership is now the new strategy for corporate growth. The power of thought leadership boosts the organizational growth and innovation by encouraging transparent knowledge sharing with strategic partners and clients. Few examples that best illustrated this are Deloitte, PwC, IBM and more. These organizations share their own best practices, knowledge, case studies and highly skilled and talented leaders to serve as value-added resources to fuel business growth. Dolan (2018) emphasized that thought leadership is external recognition of an organization, which fully understand its business, customer needs and the wider marketplace in which business operates. Having reputation of thought leadership companies would enjoy direct benefits such as increased sales, increased influence and increased opportunities. For example, thought leadership companies earn more recognition in specific field, their ideas and opinions would carry greater weights in influencing others within the industry. The professional and well-known recognized knowledge also helps in enlarging business opportunities; even have chances breaking into new markets too. Thought leadership not only benefits organization growth externally but internally too. In some ways, thought leadership becomes a critical way to attract and retain talented people, which leads to an in-depth discussion. Organizational efforts of building effective thought leadership would bring positive impacts to the employees such as increased employee engagement with positively instilled passion to organization. Through the journey, employees gain a strong sense of pride about what they contributed and the differences they made to clients' lives. Besides, it helps to cultivate culture of continuous thinking and innovation across the organization as well as increases employee morale.

\section{Differences between Thought Leadership and Traditional Leadership}

In this highly competitive market, thought leadership has been gaining greater interests of business leaders and strategists. Alhaddi (2014) pointed out that thought leadership "champion" the new ideas until the successful implementation stage. Thought leaders inspire and ignite people imaginations, reinvent old methods to better paths that others can follow. Thought leadership can be demonstrated by non-managerial employees too. Any employees with revolutionary mind-set and the capability of championing new ideas exhibits the traits of thought leadership (Alhaddi, 2015). Compared to traditional leadership, thought leadership is not easily monopolized. Other than that, Gibbins-Klein (2011) defined that thought leaders have the ability to reach other individuals in respective organizations or across the industries effectively. He also shared that the key attributes of 
INTERNATIONAL JOURNAL OF ACADEMIC RESEARCH IN BUSINESS AND SOCIAL SCIENCES Vol. 9, No. 5, May, 2019, E-ISSN: 2222-6990 @ 2019 HRMARS

thought leaders are possessing the capability of engaging with respective audience through personal communication while having the capacity to stand out as authoritative models in the organizations. Table 1 denotes the difference between thought leadership and traditional leadership.

Table 1: Thought Leadership and Traditional Leadership

\begin{tabular}{|c|c|c|}
\hline & Thought Leadership & Traditional Leadership \\
\hline Key characteristics & $\begin{array}{l}\text { Promotion of new ideas, } \\
\text { continuous improvement and } \\
\text { constant innovation }\end{array}$ & $\begin{array}{l}\text { A position or role, managing } \\
\text { people or leading group to } \\
\text { achieve goal }\end{array}$ \\
\hline Authority level & Given authority is not required & $\begin{array}{l}\text { Authority over others is given, } \\
\text { require management of other } \\
\text { people }\end{array}$ \\
\hline Leadership style & $\begin{array}{l}\text { Egalitarian, ephemeral, non- } \\
\text { hierarchical }\end{array}$ & $\begin{array}{lr}\begin{array}{l}\text { Vary in style such as } \\
\text { charismatic, }\end{array} & \text { altruistic, } \\
\text { transformational } & \text { and } \\
\text { commanding. } & \end{array}$ \\
\hline Information sharing & $\begin{array}{l}\text { Share information and } \\
\text { knowledge openly }\end{array}$ & $\begin{array}{ll}\text { Emphasize } & \text { information } \\
\text { ownership } & \end{array}$ \\
\hline Resolving issues & $\begin{array}{l}\text { Seek to uncover root causes of } \\
\text { issues, find better alternatives } \\
\text { from existing best alternative }\end{array}$ & $\begin{array}{l}\text { Solve problems when it } \\
\text { happens and focus on } \\
\text { symptoms to prevent issues } \\
\text { happen }\end{array}$ \\
\hline
\end{tabular}

Thought Leadership in the Service Industry

According to Department of Statistics Malaysia (2018), Malaysia's economy in the third quarter of 2018 has grew 4.4\% while service industry is one of the key drivers contribute for this national economy growth. Services industry $(56.0 \%)$ remained as the largest contributor to the economy. This industry expansion is fueled by the strong momentum in wholesale \& retail trade, Information \& communication and finance and insurance. Wholesale \& retail trade achieved a $9.5 \%$ growth, reflecting the outstanding performance in retail and motor vehicle. Moreover, information \& communication registered a growth of $8.4 \%$ contributed by communication and computer services activities while finance \& insurance registered a growth of $1.4 \%$, following a better growth performance in finance and continued double digit growth in insurance. The labor market condition in service industry showed a growth too. The employment in the service industry grew $2.7 \%$ and salaries and wages grew 3.9\% (Department of Statistics Malaysia, 2018). The encouraging growth of service industry in Malaysia urged the necessary of having thought leadership, especially in this digital 
and creative world. Arham (2014) stated that leadership refers to process of influencing and guiding people to achieve organizational goals. Thought leadership refers to any person or company that is recognized as a leading authority in its field where people will seek their advice and expertise. Thought leaders act as a trusted source of information who realize the ideas, know, and prove the way of replicating success. An example that best illustrate thought leadership is Tun Dr. Mahathir bin Mohamad, our current Prime Minister of Malaysia. There are also few examples of thought leadership of service industry in Malaysia such as Robert Kwok and Ananda Krishnan. Robert Kwok, the richest man in Malaysia, owning the Kuok Group, although most of the managerial work has been delegated to the next generation, he still serves as the voice of reason and counsel in Kwok Group; Ananda Krishnan, another wealthy tycoon in Malaysia, involving in telecom outfit Maxis, media firm Astro Malaysia Holdings and other services provider. They are the role models of young generation; they inspire the young generation to generate more new ideas and foster innovation. In light of the fact that there is a lack of inspirational and visionary leaders - thought leaders is the rising concern. Malaysian organizations recognize the importance of having great quality leaders, however they may not ready or do not have the necessary resources to undertake the leadership gaps (Ang, 2016).

\section{Challenges that could be addressed by Thought Leadership}

Thought leadership is different from subject matter experts. The area of expertise of thought leaders is recognized across the industry. Thought leaders need to clarify their area of expertise. As trusted source of information in the industry, they have to be clear and consistent in their expertise. When organization is ambiguous in identifying business goals, thought leadership can help to find new ideas and trends, define business goals by fueling massive knowledge. Every industry has problems and issues, thought leadership could then contribute new and innovative ideas that widen the industry perspective. In addition, thought leadership is always ahead of the industrial curve. Thought leaders in the service industry are able to anticipate the changes in business and react in a proactive manner. With fast adaptability, thought leaders could also identify and make appropriate decisions to streamline operational processes in the organizations. Thought leaders are intelligent in seizing opportunity. It is not only about innovation, but also the realization part of ideas. While planning and preparing the strategic plan, thought leaders are capable in evaluating and minimizing risks. Steffens (2018) highlighted that thought leadership is able to give narrow focus in existing or potential customers by helping them to solve their problems and or fulfilling their needs. Thought leaders have the conventional approach to determine the best alternatives on particular issues.

\section{What Thought Leadership can offer in the Digital and Creative World?}

Davis's (2015) article pointed that Industry 4.0 would conduce to a radical impact on work, education and skills. The industry competitiveness is not only limited to resource optimization but involves innovative inter-organizational value chain in the collaborative business ecosystem. Thought leadership is a significant way to deliver meaningful outcome and value to others. It is apparently that communicating by thought leadership allows an increase of brand exposure, which drives engagement with larger numbers of potential customers. Prince (2015) affirmed that thought leadership assists and supports others to achieve success. Thought leaders possess the informative content and reify innovative and actionable components as new industry standards, which create 
real business value in the industry. Besides, the benefit of having thought leadership is to create substantial increase of revenues by catching the attention of audiences and demonstrating expertise to them (Prince, 2015). For example, professional service firms are able to drive others' success by following thought leadership suggested ways to generate revenues. Fallon (2016) supported that thought leaders are able to understand industrial issues integrally and provide educative advice to deal with the issues. With constant learning, thought leaders could share and comment on the evolving trends. Thought leaders could also analyses the patterns of market dynamics, aligning hypothesis and desired achievements to overcome the existing challenges.

\section{Ways to Implement Thought Leadership}

Fallon's (2016) article stated that thought leadership needs experience and credibility building over the time. Implementing thought leadership is not easy. Thought leaders need to observe and connect sources from information pool to create ideas that needed by the marketplace. In order to implement and embrace thought leadership, leaders would need to have a voice that make them stand out from the pool of talents. The voice can refer to the passions and valuable information they share. Thought leaders can narrow down their focus to specific audience and provide the right message to the right audience. Besides, it is essential to grab attention of other industry experts too. It would never go wrong to develop relationships with industry influencers. A knowledge sharing or knowledge exchange session would definitely bring mutual benefits to both parties. The quality of possessed knowledge is important too. Educational and informative knowledge or content that related to industry trends would help thought leaders to stand out and reach target audience competently. Working towards implementing thought leadership, Hall (2014) shared the ways of creating thought leadership such as establishing strategy and goals, developing core ideas, writing and editing contents cooperate with target publication and promote efforts. Establishing strategy and goals by identifying the desired accomplishments, defining differentiation strategy, determining channels to reach target audience provides a better execution in implementation phase. Developing core ideas strategically (be organized and systematic) is essential. Keeping open mind to accept new ideas and maintain the eagerness to learn would turn thought leaders into better thought leaders. Polishing gathered insights, thoughts and ideas to coherent pieces would never be easy. Thought leaders should learn to have the ability to gather information from different sources and tailor specialized content to target audience. Preparing and presenting ideas into action is not sufficient. In this rapid technological growth era, social media platforms can be the foundation for thought leaders to develop and grow effectively too. Thought leaders and team could make use of the platforms to increase public engagement and thus contribute efforts towards achieving organizational goals. It may be added that efforts such as identifying starting point, investing time with target audience, defining prioritization areas, publishing, and engaging in effective platforms are essentials to thought leadership (Brockmeyer, 2016). Being a subject matter expert is not sufficient to compete in the digital and creative world. Now the term thought leadership adequately addresses customers' needs, priorities and diverse preferences. The key areas of thought leadership include building a thought leadership content that match with the customers' demand and offering contemporary point of view on market trends, news and new ideas to achieve success. People would naturally seek for thought leadership advice and solutions since thought leadership is now not limited to organization but 
provide advancement in industry too. Thought leaders should be able to lead others to think, inspire others to develop their potential. Brendel (2017) expressed that thought leadership can be implemented and enhanced by supplementing their expertise with three essential elements that define good leadership namely mindfulness, emotional intelligence, and strategic thinking. These elements are interrelated, mutually reinforce each other and strengthen the technical knowledge that leaders must deploy. Self-awareness and stress management skills are crucial for thought leaders to think clearly, prioritize, collaborate, and make accurate decisions. Furthermore, thought leaders with high social and emotional intelligence could have better understanding of complex environments that they embedded. Strategic thinking skills is also important for thought leaders to collaborate and lead others in generating innovative thoughts as well as implementing strong action plans.

\section{Common mistakes that should be avoided}

Forbes Coaches Council (2017) members and Marx (2018) elaborated on the common mistakes that a company should avoid when implementing thought leadership (see Table 2). 
INTERNATIONAL JOURNAL OF ACADEMIC RESEARCH IN BUSINESS AND SOCIAL SCIENCES

Vol. 9, No. 5, May, 2019, E-ISSN: 2222-6990 @ 2019 HRMARS

Table 2: Types of Common Mistakes

\begin{tabular}{|c|c|}
\hline Common mistakes & Elaboration \\
\hline Copying others & $\begin{array}{l}\text { Thought leaders should stand out from the peers by } \\
\text { putting themselves in prime position to speak up on } \\
\text { unique insights and relevant issues in the industry. } \\
\text { One of the important keys to stand out is gaining a } \\
\text { comprehensive understanding of knowledge and } \\
\text { industry trend before sharing insights to others. } \\
\text { Never follow the crowds. }\end{array}$ \\
\hline Lack of strategy & $\begin{array}{l}\text { Determining strategy is crucial in fostering thought } \\
\text { leadership. Thought leadership is a consistent and } \\
\text { long-term effort. A constant review of strategic plan } \\
\text { is required with continuous time and energy } \\
\text { investment. }\end{array}$ \\
\hline Deliver low quality content & $\begin{array}{l}\text { One of the ways of gaining recognition and authority } \\
\text { in thought leadership is the quality of deliverables. } \\
\text { With the exposure of broad areas of knowledge, } \\
\text { thought leaders have the ability to digest and } \\
\text { segment existing knowledge and offer unique } \\
\text { content that meets industry standards. Practical } \\
\text { insights and critical judgement could be shared to } \\
\text { targets in order to help others achieve their goals. }\end{array}$ \\
\hline Misleading self-perception & $\begin{array}{l}\text { People are not always right. Thought leaders should } \\
\text { always open to comments and constructive } \\
\text { feedback. An unwillingness to accept information } \\
\text { not aligned with their hypothesis is doomed to } \\
\text { failure. Recognizing and sharing professional failures } \\
\text { appropriately would increase other individuals' } \\
\text { likelihood in listening to the insights and advice } \\
\text { thought leaders provide. }\end{array}$ \\
\hline Emphasis on self-promotion & $\begin{array}{l}\text { In fact, thought leadership should focus on } \\
\text { customers' needs. Thought leaders could provide } \\
\text { advices and inputs that show their industry } \\
\text { expertise, feed customers with valuable insights on } \\
\text { trending issues and new solutions. }\end{array}$ \\
\hline
\end{tabular}

\section{Conclusion}

In short, the role of thought leaders is to provide unique insight towards latest trends on a specific field with a continuous passion in pursuing innovation and ideas improvement. Implementing 
INTERNATIONAL JOURNAL OF ACADEMIC RESEARCH IN BUSINESS AND SOCIAL SCIENCES Vol. 9, No. 5, May, 2019, E-ISSN: 2222-6990 @ 2019 HRMARS

thought leadership strategy is critical to achieve organizational goals and elevate organization in the industries. With the objective of growing business and maximizing the success, thought leaders are required to be strategic and be proactive consistently. A continuous effort in thought leadership strategy will definitely bring about powerful yet significant impact of taking part in influencing changes in the respective industry. While working on implementing thought leadership, it is also essential to give concern in minimizing potential mistakes that easily been neglected to ensure the effectiveness of thought leadership implementation in the industry.

\section{Acknowledgements}

The authors would like to thank the Malaysian Ministry of Higher Education and Universiti Teknologi Malaysia (GUP-Vot: 14J81) for providing financial support to publish this paper.

\section{References}

Alhaddi, H. (2014). The relationship between thought leadership and innovation: a look at strategy. Journal of Business Administration and Education, 6(2), 57-65.

Alhaddi, H. (2015). Innovators or thought leaders: what do organizations need? International Journal of Managerial Studies and Research, 3(2), 54-58.

Ang, J. (2016). Malaysian firms are struggling to develop leaders. Retrieved from https://www.humanresourcesonline.net/leadership-top-priority-business-leaders-sea/

Arham, A. F. (2014). Leadership and performance: the case of Malaysian SMEs in the services sector. International Journal of Asian Social Science, 4(3), 343-355.

Brendel, D. (2017). It is time to revisit the concept of thought leadership. Retrieved from https://www.huffingtonpost.com/david-brendel/its-time-to-revisit-the-c_b_9979600.html

Brockmeyer, M. (2016). Thought leadership is different in tech. Here's what to do about it.

Davis, N. (2015). Five ways of understanding the Fourth Industrial Revolution. Retrieved from https://www.weforum.org/agenda/2015/11/5-ways-of-understanding-the-fourth-indust realrevolution/

Department of Statistics Malaysia, (2018). Malaysia economic performance third quarter 2018.

Dolan, G. (2018). The benefits of thought leadership for companies. Retrieved from https://www.theceomagazine.com/business/management-leadership/the-benefits-of-th

ought- leadership-for-companies/

Fallon, N. (2016). What is thought leadership, and why does it matter? Retrieved from https://www.businessnewsdaily.com/9253-thought-leadership.html

Forbes Coaches Council. (2017). 10 mistakes you're making when building thought leadership. Retrieved from https://www.forbes.com/sites/forbescoachescouncil/2017/01/17/10-mistakesyou're-making-when-building-your-thought-leadership/\#11cdb42e45a5

Gibbins-Klein, M. (2011). Winning by thinking: how to create a culture of thought leadership in your organization. Development and Learning in Organizations, 25(1), 8-10.

Hall, J. (2014). How to create a company of thought leaders. Retrieved from https://www.forbes.com/sites/johnhall/2014/06/15/how-to-create-a-company-of-thoughtleaders/\#5812297e44d8 
Israel, S. (2012). What makes a thought leader? Retrieved from https://www.forbes.com/site s/shelisrael/2012/03/05/what-makes-a-thought-leader/\#22 d4d5165c45

Llopis, G. (2014). Thought leadership is the new strategy for corporate growth. Retrieved from https://www.forbes.com/sites/glennllopis/2014/08/18/thought-leadership-is-the-newstrategy- for-corporate-growth/\#29deca0e2b43

Marx, W. (2018). Thought leadership strategy: the 10 biggest mistakes you need to avoid. Retrieved from https://www.business2community.com/leadership/thought-leadership-strategy-the-10biggest-mistakes-you-need-to-avoid-02047612

McCrimmon, M. (2005). Thought leadership: a radical departure from traditional, positional leadership. Management Decision. 43(7/8), 1064-1070.

Prince, R. A. (2015). The two key benefits of thought leadership done well. Retrieved from https://www.forbes.com/sites/russalanprince/2015/06/08/the-two-key-benefits-of-thoughtleadership-done-well/\#6958db6e4aaa

Steffens, R. (2018). A step-by-step guide to creating thought leadership content. Retrieved from https://www.bluleadz.com/blog/a-step-by-step-guide-to-creating-thought-leadership-content 